\title{
The C. elegans DAF-2 Insulin-Like Receptor is Abundantly Expressed in the Nervous System and Regulated by Nutritional Status
}

\author{
K.D. KIMURA ${ }^{1,4}$, D.L. RIDDLE ${ }^{3}$, AND G. RUvKUN ${ }^{1,2}$ \\ ${ }^{1}$ Department of Molecular Biology, Massachusetts General Hospital, Boston, Massachusetts 02114 \\ ${ }^{2}$ Department of Genetics, Harvard Medical School, Boston, Massachusetts 02115 \\ ${ }^{3}$ Michael Smith Laboratories and Department of Medical Genetics, The University of British Columbia, \\ Vancouver, British Columbia, Canada V6T1Z4 \\ Correspondence: ruvkun@molbio.mgh.harvard.edu
}

\begin{abstract}
A Caenorhabditis elegans insulin-like signaling pathway regulates development, metabolism, and longevity. We detected abundant DAF-2 insulin-like receptor protein mainly in the nervous system, consistent with the assignment of DAF-2 pathway regulation of longevity to the nervous system. DAF-2 abundance in the nervous system is dependent on food intake, showing environmental modulation of pathway signaling. DAF-2 abundance is not dependent on downstream PI-3 kinase to DAF-16 transcription factor signaling. The modulation of DAF-2 protein level by nutritional status may constitute an important component in the irreversible commitment to dauer arrest.
\end{abstract}

Insulin, insulin-like growth factor (IGF-I), and their homologous signaling pathways regulate metabolism, growth, and longevity in vertebrates and invertebrates (Finch and Ruvkun 2001; Porte et al. 2005; Taguchi and White 2008). In mammals, insulin is secreted from pancreatic $\beta$-cells in response to blood glucose, binds to and activates its receptor expressed in a wide variety of cells, and causes glucose uptake and incorporation into macromolecules in liver, fat, and muscle. IGF-I is secreted from the liver in response to growth hormone from the pituitary gland and promotes cell growth in a variety of tissues.

An insulin/IGF-I signaling pathway regulates Caenorhabditis elegans development, metabolism, and longevity. The pathway consists of many insulin-like ligands, DAF-2 insulin/IGF-I receptor, AGE-1 PI-3 kinase, DAF-18 PTEN protein/lipid phosphatase, PDK-1, AKT1 , and AKT-2 protein kinases, and the target of these kinases, the DAF-16 fork head transcription factor (Morris et al. 1996; Kimura et al. 1997; Ogg et al. 1997; Ogg and Ruvkun 1998; Paradis and Ruvkun 1998; Paradis et al. 1999; Pierce et al. 2001). Genetic evidence suggests that, under optimal environmental conditions, the $d a f-2$ signaling pathway is activated to trigger reproductive development and fast metabolism (Vowels and Thomas 1992; Thomas et al. 1993; Gottlieb and Ruvkun 1994) and a relatively short life span of $2-3 \mathrm{wk}$. When environmental conditions are not suitable for reproductive growth, for example, under conditions of higher than optimal temperature, crowding, and low food abundance, daf-2 pathway signaling is decreased and animals arrest development at the dauer larval stage, storing large amounts of fat instead of shunting energy to the reproductive system (for review, see Riddle and Albert 1997). Dauer larvae are resistant to various stresses and live for up to several months. Even in adult animals in which the daf-2 pathway signaling is decreased by shifting a temperature-sensitive daf-2 mutant to a nonpermissive temperature, metabolism is shifted to fat storage, and longevity is increased (Kenyon et al. 1993; Dorman et al. 1995; Larsen et al. 1995).

Many of the molecular components of the insulin signaling pathway, including the output to metabolic control and aging, are conserved between humans and worms. Mammalian caloric restriction leads to decreased insulin/IGF-I signaling, and mice with defects in growth hormone signaling (which also leads to decreased IGF-I signaling) have a lengthened life span (Brown-Borg et al. 1996; Bartke et al. 1998; Bruning et al. 2000). In addition, brain-specific reduction of the insulin receptor or the insulin receptor substrate-2 also extends life span (Bruning et al. 2000; Taguchi and White 2008). Thus, the regulation of life span and metabolism by this pathway may be ancient and conserved.

We show here with anti-DAF-2 antibodies that DAF-2 protein is expressed at the highest levels in neurons and localizes to the nerve ring, the worm brain. This result is consistent with the analyses showing that $d a f-2$ activity is required mainly in neurons to regulate longevity (Wolkow et al. 2000). We also show that DAF-2 abundance is positively correlated with $d a f-2$ gene activity. The regulation is not dependent on the age-1/akt/daf-16 signaling pathway, suggesting that DAF-2 abundance is dependent on its engagement of ligands or another DAF-2 output

\footnotetext{
${ }^{4}$ Present address: Department of Biological Sciences, Graduate School of Science, Osaka University, Osaka 560-0043, Japan. Copyright (C) 2011 Cold Spring Harbor Laboratory Press; all rights reserved; doi: 10.1101/sqb.2011.76.010660 
besides the AKT to DAF-16 pathway. We also report that nonsense mutations in $d a f-2$, which result in no detectable DAF-2 protein, cause arrest at the dauer stage, showing that the DAF-2 insulin receptor mainly couples to these metabolic functions.

\section{RESULTS}

\section{Molecular Identification of $d a f-2$ Null Alleles}

We determined the DNA sequence of exons from the ligand-binding (exon 9) and kinase (exon 14) domains from a set of six $d a f-2$ alleles that arrest at the dauer stage at all temperatures. Three of these daf-2 alleles are nonsense mutations, located just after the ligand-binding domain, in the juxtamembrane domain, and the kinase domain. Nonsense mutations were detected for $m 65$ G4466A (W1449stop), m646 C3787T (Q1223stop), and m698 C2149T (Q677stop). In addition, a missense substitution in the non-ts daf-2 allele m633 G4649A (R1510H) was detected; this amino acid residue in the kinase domain is conserved throughout the protein kinases. The $m 65, m 646$, and $m 633$ substitutions were independently determined by Patel et al. (2008). All three alleles cause dauer arrest at $15^{\circ} \mathrm{C}, 20^{\circ} \mathrm{C}$, and $25^{\circ} \mathrm{C}$ when homozygous (e.g., all of the 2450 homozygotes of $d a f-2(m 65)$ from a balanced heterozygous strain arrested at the dauer stage). The daf-2(m65) allele also causes low-penetrance embryonic lethality (Gems et al. 1998). It is likely that the phenotype of zygotic plus maternal $d a f-2$ loss will be a more severe embryonic lethal phenotype. An analysis of germline mosaic animals is necessary to analyze this problem. Because these alleles are predicted to truncate the DAF-2 protein upstream of, or in, essential regions such as the juxtamembrane and kinase domains, and because they do not express detectable DAF-2 protein (see below), they are probably null alleles. The null alleles were used as a negative control for immunofluorescent analyses of the protein.

\section{DAF-2 is Localized to Neuronal Processes and Cell Bodies}

We raised and affinity-purified rabbit anti-DAF-2 antisera using as an immunogen a GST fusion protein bearing a DAF-2 coding region corresponding to the cytoplasmic kinase domain plus a 264-amino-acid carboxy terminal to this domain. The purified antibodies recognized recombinant DAF-2 protein expressed in bacteria with high specificity (Fig. 1A). In indirect immunofluorescence experiments, the purified antibodies revealed DAF-2 in the cell bodies and processes of neurons, most obviously in the nerve ring, the major neuropil of the animal (Fig. 1B). DAF-2 was also expressed in the cell bodies of a pair of cells anterior to the nerve ring that were identified as XXXL/R, based on their variable positions relative to the nerve ring from animal to animal. No such immunofluorescence was observed in the daf-2(m646) null mutant (Fig. 1C), indicating that the antibodies are specific to DAF-2. Whereas the highest

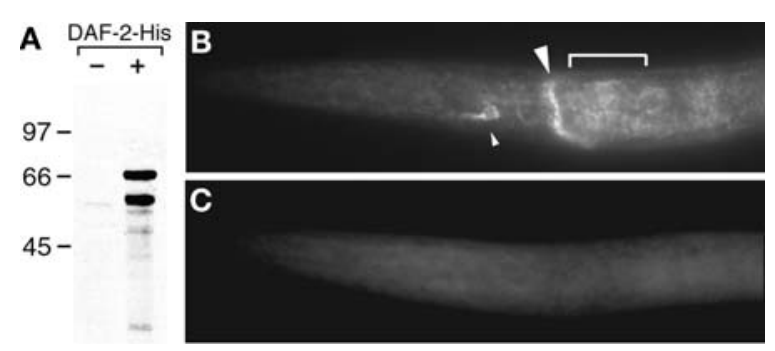

Figure 1. Neuronal localization of DAF-2 protein in wild-type worms. (A) Specificity of anti-DAF-2 antiserum. A $0.3 \mu \mathrm{g}$ aliquot of host bacteria BL21(DE3) protein was loaded on both lanes, and $1 \mathrm{ng}$ of the recombinant DAF-2 protein was loaded on the "+" lane. The DAF-2 gene product $(67.5 \mathrm{kDa}$ by prediction) and its degradation products were specifically detected. $(B)$ Lateral views of fixed wild-type and $(C)$ daf-2(m646) null mutant animals that were incubated with affinity-purified anti-DAF-2 antibodies detected with a fluorescent secondary antibody. Large and small arrowheads and bracket indicate nerve ring, XXXL/R cells, and neuronal cell bodies, respectively, in this figure and in Figs. 2-4. No immunofluorescence was detected in daf-16(m27);daf-2(m646) (C), although daf$16(\mathrm{~m} 27)$ showed the same fluorescent signal as the wild type (data not shown).

level of DAF-2 was present in the nervous system, we also observed weak immunofluorescence in other tissues, such as the hypodermis (data not shown). This is consistent with GFP fusions to daf-2 that show expression in nonneuronal as well as neuronal tissues (M Costa, pers. comm.).

DAF-2 is present in neurons at the time that its activity is required. Experiments using temperature-sensitive $d a f-2$ alleles showed that $d a f-2$ signaling is required during the late-L1 stage to specify reproductive development rather than dauer arrest (Swanson and Riddle 1981) and is required during the adult stage for normal adult senescence (Kenyon et al. 1993; Dorman et al. 1995; Larsen et al. 1995). We observed DAF-2 in the nerve ring from the mid-L1 stage to adulthood (Fig. 2).

\section{DAF-2 Level is Regulated by Environmental Signals}

Dauer-inducing pheromones, food, and temperature normally regulate dauer arrest (Golden and Riddle 1982, 1984; Jeong et al. 2005; Butcher et al. 2007). These environmental cues normally regulate the activity of the daf-2 pathway. Because starvation is a strong cue for dauer arrest, we examined DAF-2 abundance in starved versus well-fed wild-type animals. DAF-2 protein levels decreased dramatically in wild-type animals cultivated in the absence of food for $24 \mathrm{~h}$ compared with well-fed animals (Fig. 3). This suggests that the DAF-2 abundance is coupled to nutritional status or the sensation of food.

The abundance of DAF-2 was also decreased in daf-2 mutants. In animals carrying temperature-sensitive daf-2 mutations (e1370 and sa187), DAF-2 immunofluorescence decreased significantly after upshift to the nonpermissive temperature. In the wild type, such a temperature shift caused a small decrease in DAF-2 protein level (Fig. 4A,B), but the decrease was much more dramatic 

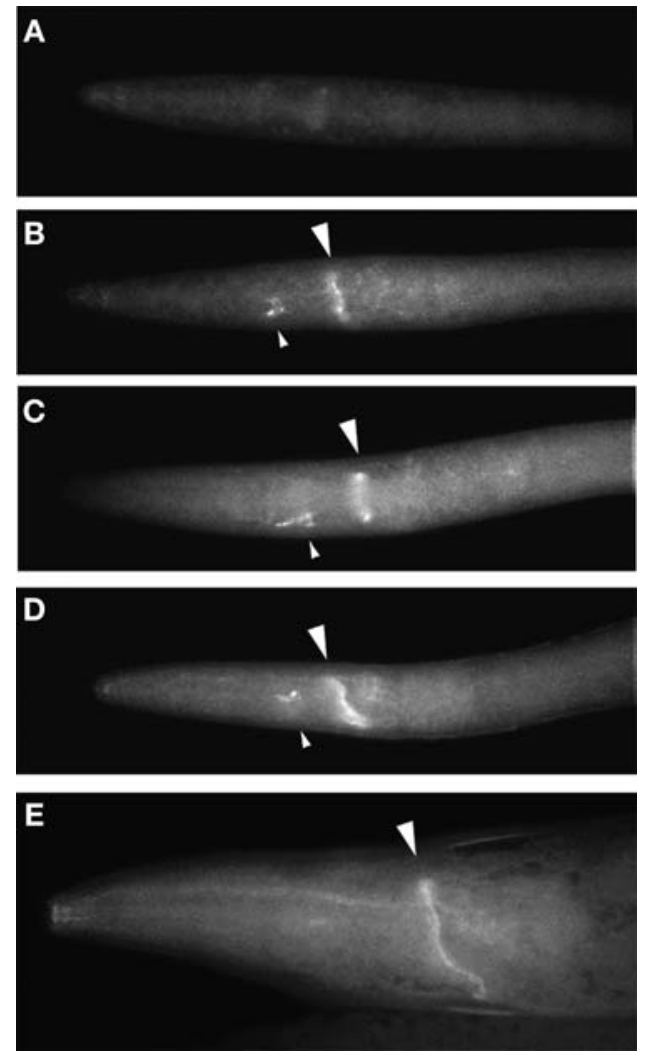

Figure 2. Expression of DAF-2 protein in developmental stages. DAF-2 expression in the nerve ring begins during larval-stage 1 and continues at all subsequent stages. Wild-type animals at each stage were immunofluorescently labeled with the purified anti-DAF-2 antibodies. Stages are $(A)$ early L1, $(B)$ mid L1, $(C) \mathrm{L} 2,(D) \mathrm{L} 4$, and $(E)$ adult.

in the daf-2 mutants (Fig. 4C,D). In some upshifted $d a f-2$ mutant animals, DAF-2 protein disappeared entirely from the nerve ring and only remained in sensory processes and cell bodies. Animals with no DAF-2 protein were also observed. The results suggest that when DAF-2 activity is decreased, DAF-2 protein is first lost from the nerve ring and subsequently from processes and cell bodies. A more trivial interpretation is that these mutations destabilize the DAF-2 protein; the analysis of mutations in the downstream insulin signaling cascade analyzed below distinguishes between these models.

The daf-2 alleles with mutations either in the tyrosine kinase domain (e1370) or in the ligand-binding domain (sa187) showed a decrease in DAF-2 abundance (Fig. 4C,D,G), suggesting that the loss of DAF-2 activity rather than, for example, DAF-2 protein folding or sorting defects may cause the decrease in abundance. Such a model of DAF-2 activity-dependent control of DAF-2 abundance is favored by the observation that starvation also caused a dramatic decline in DAF-2 protein abundance (Fig. 3).

If there is a $d a f-2$ autoregulatory signaling pathway, it does not use the canonical PI-3 kinase to AKT to DAF16 transcription factor output. For example, a mutation in daf-16, the transcriptional output of $d a f-2$ signaling, did not change DAF-2 protein level (Fig. 4E,F). In addition, a mutation in the age-1 PI-3 kinase, an immediate downstream effector of $d a f-2$, did not cause a decrease in DAF-2 protein level (Fig. $4 \mathrm{H}$ ). DAF-2 protein level was also unaffected by a mutation in $d a f-7$, a TGF- $\beta$ homolog that also regulates dauer arrest (Fig. 4I), suggesting that this pathway is not involved in the regulation.

These results suggest that food modulates the production of insulin-like DAF-2 ligands, which in turn affect DAF-2 activity and DAF-2 abundance. For example, the regulation of DAF-2 abundance could occur via, for example, modulation of receptor-mediated endocytosis or a DAF-2-activity-dependent feedback mechanism of DAF-2 abundance that is mediated by a signaling pathway distinct from the AGE-1/AKT/DAF-16 pathway.

\section{DISCUSSION}

DAF-2 protein is expressed in neurons and localizes to the nerve ring. The high level of DAF-2 in the nerve ring is consistent with the finding that a major site-of-action of daf-2 signaling is neurons (Wolkow et al. 2000). The daf-2 functions cell nonautonomously based on mosaicand tissue-specific expression analyses (Apfeld and Kenyon 1998; Wolkow et al. 2000). DAF-2 may regulate neuronal activity and/or the secretion of reproduction- and longevity-regulating hormones from the nervous system. The expression of DAF-2 strongly in the XXX secretory cell is also consistent with this model. The $\mathrm{XXX}(\mathrm{L} / \mathrm{R})$ cells regulate dauer arrest, based on laser ablation and genetic studies; for example, production of the ligand for the DAF-12 nuclear hormone receptor by the cytochrome p450 DAF-9 occurs in the XXX cells (Ohkura et al. 2003; Gerisch and Antebi 2004). In the adult, each XXX cell extends a process that faces the pseudocoelom outside the pharynx. The XXX cells have no intercellular junctions and make no obvious synapses, but they remain in close contact with labial neurons and the hypodermis. They have abundant ribosomes, smooth

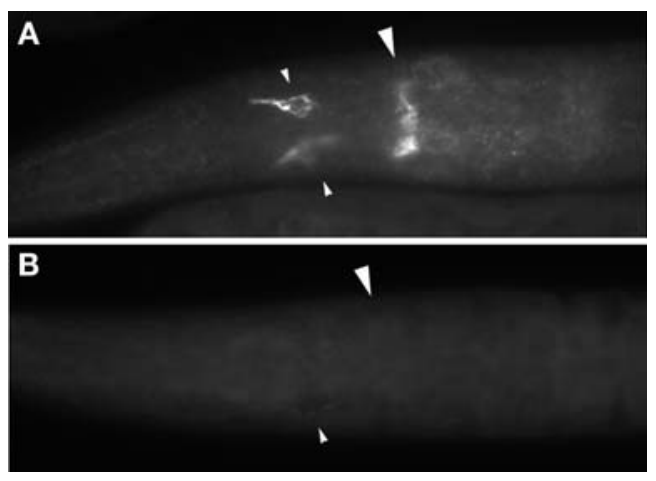

Figure 3. Starvation-induced down-regulation of DAF-2 protein. Ventral views of wild-type animals that were $(A)$ well fed or $(B)$ starved for $24 \mathrm{~h}$ at $15^{\circ} \mathrm{C}$ and subsequently fixed and immunofluorescently labeled with the purified anti-DAF-2 antibodies. 

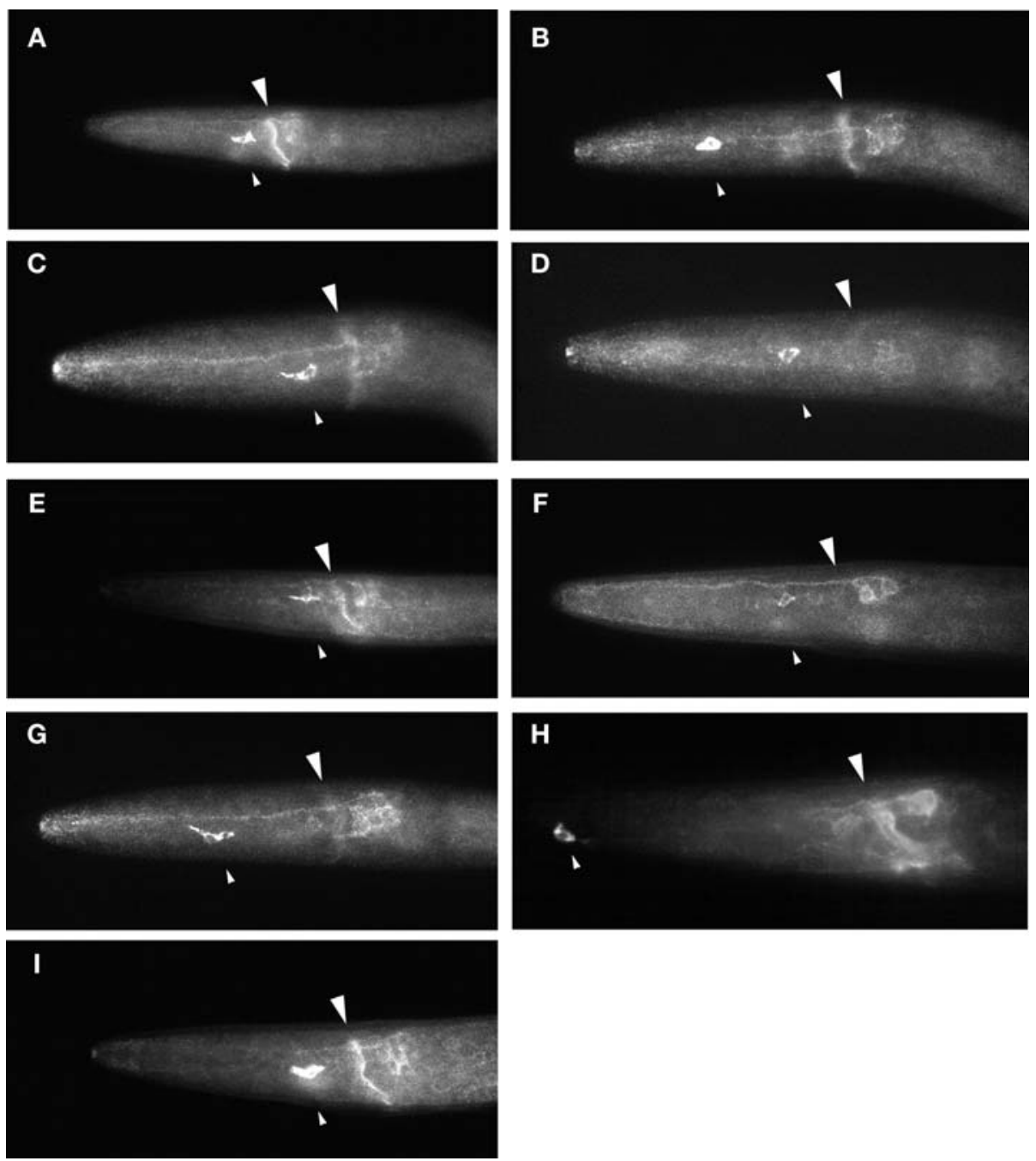

Figure 4. DAF-2 expression in daf-2 pathway mutants. Animals bearing mutations in daf-2, age-1, or daf-7, and control animals, were fixed and immunofluorescently labeled with affinity-purified anti-DAF-2 antibodies. $(A)$ Wild-type animal grown at $15^{\circ} \mathrm{C},(B)$ wildtype animal at $25^{\circ} \mathrm{C},(C)$ daf-2(e1370) at $15^{\circ} \mathrm{C},(D)$ daf-2(e1370) at $25^{\circ} \mathrm{C},(E)$ daf-16(mgDf50); daf-2(e1370) at $15^{\circ} \mathrm{C},(F)$ daf-16(mgDf50);daf-2(e1370) at $25^{\circ} \mathrm{C},(\mathrm{G})$ daf-2(sal 87$)$ at $15^{\circ} \mathrm{C},(\mathrm{H})$ daf-16(m27);age- $1(\mathrm{mg} 44)$ at $20^{\circ} \mathrm{C}$, and $(\mathrm{I})$ daf-7 at $25^{\circ} \mathrm{C}$. The daf-16 mutations had no effect on DAF-2 abundunce and were included to suppress dauer arrest so that adult expression could be compared.

endoplasmic reticulum, and a few vesicles (White et al. 1986). The XXX cell has been strongly implicated in regulation of dauer arrest by the C. elegans insulin signaling pathway but not in life-span regulation. We know that for dauer arrest the insulin signaling pathway is coupled to the production of small-molecule ligand by the DAF-9 cytochrome $\mathrm{p} 450$ protein for the DAF-12 nuclear hormone receptor. If the more extensively studied dauer arrest program of the insulin signaling pathway uses similar output principles to the longevity program, the other neurons that express DAF-2 could couple to nonneuronal tissues via other members of the extensive p450 cytochrome family of C. elegans (Thomas 2006).

The model of hormonal signaling from neurons downstream of an insulin-like receptor signaling pathway is consistent with several examples of animal insulin/ IGF-I-like signaling in nervous systems that induce hor- monal secretions (Ishizaki and Suzuki 1994; Graf et al. 1997; Jonas et al. 1997; Bruning et al. 2000; Taguchi and White 2008).

Insulin and IGF-I signaling have been noted in mammalian brain (for review, see Plum et al. 2005; Aleman and Torres-Aleman 2009). In addition, the insulin receptor-related receptor is expressed in cholinergic neurons of the central nervous system and dorsal root ganglia (Tsuji et al. 1996). The mammalian insulin receptor is required in pancreatic $\beta$-cells, which have many features of neurons, for insulin secretion (Kulkarni et al. 1999). Insulin receptor signaling, more generally in the nervous system, is also necessary for normal glucose control as well as control of appetite (Bruning et al. 2000; Schwartz et al. 2000). Thus, DAF-2 signaling in the C. elegans nerve ring may similarly control metabolism and feeding as part of its function to regulate diapause and aging. 
Alternatively, IGF-I signaling, including PI-3 kinase and Akt, suppresses neuronal apoptosis when it is activated (for review, see Werner and Le Roith 1997). However, it is unlikely that the role of $d a f-2$ in $C$. elegans neurons is to suppress apoptosis because loss of daf-2 activity does not result in neuronal cell death. For example, dauer larvae induced by temperature upshift of a daf-2 ts mutant can recover from dauer arrest and experence normal reproductive growth, suggesting that there is no loss of essential neurons. Another model is that $d a f-2$ regulates neuronal cell division and growth just as IGF-I promotes cell division and growth in mammals (for review, see LeRoith et al. 1997; Werner and Le Roith 1997). However, this is unlikely because loss of $d a f-2$ activity in adulthood during which no cell division takes place causes life-span extension, indicating that $d a f-2$ activity is continuously required at a stage when no cell division occurs.

IGF-I signaling has also been implicated in neuronal secretion. The IGF-I receptor in mammalian neurons modulates $\mathrm{N}$ - and L-type voltage-dependent calcium channels (VDCCs) in a PI-3-kinase- and Akt-dependent manner (Blair and Marshall 1997; Blair et al. 1999), possibly via promotion of trafficking of the channels to the plasma membrane (Viard et al. 2004). An electron microscopic study revealed that the IGF-I receptor is localized to pre- and postsynaptic terminals (Garcia-Segura et al. 1997). The L-type calcium channel is important for insulin secretion from pancreatic $\beta$-cells (Ashcroft et al. 1994; Bokvist et al. 1995), suggesting that the insulin receptor may similarly modulate the calcium channel in $\beta$-cells. Because VDCCs regulate neuronal excitation and secretion of neurotransmitters and hormones, DAF-2 and its mammalian orthologs may regulate hormonal release through modulation of VDCC. The localization of DAF-2 protein to the nerve ring, the primary site for synaptic connections of many neurons, also supports this idea. Because the DAF-16 transcription factor is a major output of DAF-2, insulin-like signaling in C. elegans as well as mammals may also regulate the transcription of hormones and/or neurotransmitters over longer time scales.

The single insulin-like receptor in C. elegans and Drosophila, both members of the ecdysozoan clade of animals, is probably ancestral to the three insulin receptor superfamily members in the human genome. The duplicated and diverged mammalian insulin receptor superfamily members have taken on distinct but related functions: regulation of growth and metabolism in the case of the insulin receptor, regulation of growth in the case of the IGF-I receptor, and an unknown function in the case of the insulin-receptor-related receptor (Kahn and Weir 1994). The neuronal localization of DAF-2, and the function from that tissue to regulate organismal aging, may reveal the ancestral function of this receptor type. Whereas the function of the mammalian IRR pathway is unknown, it is interesting that its expression mainly in neurons is similar to $d a f-2$.

Starvation down-regulates DAF-2 abundance. This is the first evidence that environmental conditions actually modulate signaling capacity in the DAF-2 pathway. We hypothesize that, under conditions of low nutrition that induce dauer arrest, the expression and/or secretion of DAF-2 ligands may be modulated. There are 37 such insulin/IGF-I-like molecules in the worm genome (Pierce et al. 2001). For example, ins- 1 and ins-18 have been shown to be antagonists; these genes may be activated by low nutrition to cause a decrease in daf-2 activity (Pierce et al. 2001). This may down-regulate DAF-2 abundance directly, for example, by inducing endocytosis and degradation of nonsignaling receptors.

Alternatively, a decrease in insulin-like agonist or an increase in an antagonist may cause a decrease in DAF-2 kinase activity, which in turn induces down-regulation of the DAF-2 protein itself. Such a model is favored by our observation that DAF-2 protein level is decreased in two independent temperature-sensitive mutants at the nonpermissive temperature. These results suggest that the DAF-2 protein level is positively autoregulated. However, it is also possible that the two daf-2 alleles cause an unstable protein.

Regulation of DAF-2 protein level is independent of the known components of the DAF-2 signaling pathway, such as AGE-1 PI-3 kinase and DAF-16 FOXO transcription factor (Fig. 4). The daf-16-independent daf-2 functions have been reported in the regulation of life span, learning, and autophagy (Apfeld et al. 2004; Tomioka et al. 2006; Hansen et al. 2008). Insulin and IGF-I receptors in mammals have multiple downstream signaling outputs, so it is likely that DAF-2 also has multiple outputs. In fact, DAF-2 has several tyrosine residues that are likely to be phosphorylated by its own kinase activity and subsequently bind to $\mathrm{SH} 2$ domains of signaling molecules that are distinct from the AGE-1 adaptor protein (Kimura et al. 1997). The down-regulation of DAF-2 could be mediated by a second pathway that emanates from the DAF-2 receptor output (Paradis and Ruvkun 1998; Paradis et al. 1999) or from regulation of the sorting and cell biology of the DAF-2 receptor that is not along the actual signaling pathway.

A model of positive DAF-2 autoregulation is attractive for the commitment to dauer arrest: This feedback mechanism may cause an irreversible entry into dauer arrest that can only be reversed after new DAF-2 synthesis ensues. The feedback mechanism forces a commitment to the dauer or nondauer stage.

The expression of DAF-2 in the nervous system fits well with the observation that it is insulin signaling within the nervous system that regulates aging. The modulation of DAF-2 protein levels by feeding is the first evidence that the level of signaling within the DAF-2 pathway is modulated by environmental inputs. It is likely that it is the expression or release of some of the 37 insulins in the worm genome that modulates DAF-2 activity and abundance. Because cell-non-autonomous regulation of growth and reproduction by insulin-like signaling in nervous system is a conserved mechanism, analyses of the $d a f-2$ pathway may reveal a general molecular mechanism of insulin-like signaling pathways in the nervous system. 


\section{MATERIALS AND METHODS}

\section{Nematode Strains and Culture}

Strains were maintained as described in Sulston and Hodgkin (1988). Non-ts daf-2 mutant alleles used in this study $(m 65, m 631, m 633, m 643, m 646$, and m698) were isolated from a genetic screen described in Gems et al. (1998) and maintained as heterozygotes with the balancer chromosome $q C 1$ [dpy-19(e1259) $g l p-1(q 339)]$ or as a double mutant with daf-16(m26) or daf-16(m27).

\section{Sequencing daf-2 Alleles}

Dauer progeny from the heterozygote $d a f-2$ alleles or progeny from $d a f-16(m 26) ; d a f-2(m 65)$ were picked into worm lysis buffer $(50 \mathrm{mM} \mathrm{KCl}, 10 \mathrm{mM}$ Tris-Cl $[\mathrm{pH}$ 8.2], $2.5 \mathrm{mM} \mathrm{MgCl}_{2}, 0.45 \%$ Nonidet P (NP)-40, 0.45\% Tween-20, $0.01 \%$ gelatin) with $50 \mu \mathrm{g} / \mathrm{mL}$ of proteinase $\mathrm{K}$. The samples were frozen and thawed three times and incubated for $60 \mathrm{~min}$ at $60^{\circ} \mathrm{C}$ followed by $15 \mathrm{~min}$ at $95^{\circ} \mathrm{C}$. The samples were directly used as templates for polymerase chain reaction (PCR). Oligonucleotides TGCGAAGAGGATAAAGGCGA with TCCGAATCGACTTGCGCTAG, and TCTCAGTAACGGCGACCTC with GTTGGCACATCATTCTCTCG were used to amplify exons containing the daf-2 ligand-binding and tyrosine kinase domains, respectively. The PCR products were directly sequenced.

\section{Dauer Formation Assay}

The $q C 1[d p y-19 \quad g l p-1] / d a f-2(m 65) \quad u n c-32(e 189)$ strain was grown at $15^{\circ} \mathrm{C}$ and 35 individual $q C 1[d p y-19$ glp-1]/daf-2(m65) unc-32(e189) progeny were brooded at $15^{\circ} \mathrm{C}$. From the 35 plates, a total of 2450 Daf-c Unc progeny were produced, and no Unc adults were found.

\section{DNA Construction}

For the GST-DAF-2 fusion protein, part of the daf-2 cDNA corresponding to the kinase domain and the following 264 amino acid residues were amplified by PCR with oligonucleotides CGCGGATCCGATTGGGAGCTACGGCAGG and CGCGGATCCGGGTAGTTGAGTTAATCG, both of which have an additional BamHI site for cloning. The PCR product was cut with BamHI and cloned into pGEX-2T (Pharmacia Biotech). The plasmid was transformed into $\mathrm{DH} 5 \alpha$ and the fusion protein was induced by IPTG. For antibody purification, the kinase domain and/or the carboxy-terminal extension were each cloned into pET-21a $\mathrm{a}^{+}$(Novagen) to make a fusion protein with His $\bullet$ Tag. To make the fusion proteins, the following oligonucleotides were used, in which BamHI or NotI sites were added for cloning to forward or reverse primer, respectively: For the fusion protein including the kinase domain and the carboxy-terminal extension ("DAF-2-His"), CGCGGATCCAACATTCAAGTACGCTACGG and ATAGTTTAGCGGCCGCTCCGGGTAGTTGAGTTAATCG; for the fusion protein with only with the kinase domain ("Kinase-His"), CGCGGATCCGATTGGGAGCTACGGCAGG and ATAGTTTAGCGGCCGCCAGTGCTTCTGAATCGTC; and for the fusion protein with only with the carboxy-terminal extension ("C-ter-His"), CGCGGATCCGACGATTCAGAAGCACTG and ATAGTTTAGCGGCCGCTCCGGGTAGTTGAGTTAATCG. PCR products were cut with BamHI and NotI, cloned into the pET-21 ${ }^{+}$vector, and transformed into BL21(DE3) for induction.

\section{Production of Antisera}

For anti-GST-DAF-2 fusion protein antisera, GSTDAF-2 fusion protein with host bacteria protein was fractioned as $1 \%$ Triton-X 100 -insoluble material and mixed with Laemmli's loading buffer. The sample was electrophoresed on SDS-polyacrylamide gel, and the GST-DAF-2 fusion protein was excised from the gel following visualization by $100 \mathrm{mM} \mathrm{KCl}$ staining. The gel slices were lyophilized, ground into a powder, rehydrated, and prepared for injection. The sample was injected into two rabbits at a dose of $250 \mu \mathrm{g}$ of protein with Freund's complete adjuvant in the first injection, and $125 \mu \mathrm{g}$ with Freund's incomplete adjuvant in the following injections. The rabbits were boosted every third week five times and bled at $10 \mathrm{~d}$ after each boost. The antisera were tested on western blots of DAF-2-His fusion protein expressed in bacteria.

\section{Western Blotting}

The samples were electrophoresed on $8 \%-12 \%$ SDSpolyacrylamide gels and transferred onto Immobilon-P membranes (Millipore). After incubation with Tris-buffered saline (TBS)-Triton buffer (TBS and $0.1 \%$ Triton $\mathrm{X}-100$ ) containing $3 \%$ bovine serum albumin (BSA) for $2 \mathrm{~h}$, the membrane was incubated with primary antibodies for $2 \mathrm{~h}$, followed by brief washing with TBS-Triton buffer, and incubated with horseradish peroxidase-conjugated antimouse IgG goat antibodies 1:10,000 for $30 \mathrm{~min}$. After washing with TBS-Triton buffer for $30 \mathrm{~min}$, bands were visualized by the ECL system (Amersham Corp.).

\section{Antibody Purification}

The anti-GST-DAF-2 antisera were purified by affinity chromatography. The antisera were absorbed to an acetone-insoluble fraction of bacterial protein with GST coupled to $\mathrm{CH}$ Sepharose (Pharmacia Biotech) before the purification to remove nonspecific binding antibodies. The antisera were then loaded onto a His $\bullet$ Bind resin column (Novagen) coupled to the DAF-2 kinase domainHis or DAF-2 carboxy-terminal region-His proteins. The column was washed subsequently with $1.5 \mathrm{M} \mathrm{NaCl} / 1 \%$ Triton X-100, with $150 \mathrm{~mm} \mathrm{NaCl}$, and with $100 \mathrm{mM}$ glycine $(\mathrm{pH} 3.5)$, and then the antibodies were eluted with $100 \mathrm{~mm}$ glycine $(\mathrm{pH} 2.5)$. The eluate was immediately mixed with $1 / 10$ volumes of $1 \mathrm{M}$ Tris- $\mathrm{Cl}(\mathrm{pH} \mathrm{8.0)}$ ) and $1 / 30$ volumes of $3 \% \mathrm{BSA}$ for stabilization. The extra 
washing step with glycine $\mathrm{pH} 3.5$ was required to remove background signals. The earlier test bleeds of the antiGST-DAF-2 antisera showed higher cross-reactivity to the carboxy-terminal-His fusion protein than to the kinase-domain-His fusion in western blotting. In addition, the carboxy-terminal-His fusion was soluble in $1 \%$ Triton $\mathrm{X}-100$ but the kinase-domain-His was not. Therefore, we purified antibodies using the carboxy-terminal-His and the kinase-domain-His fusion proteins separately. The anti-carboxy-terminal antibodies had virtually no crossreactivity as assayed by immunohistochemical analyses and were used throughout this work. We were also able to purify antikinase antibodies and they showed a similar pattern in immunofluorescent analyses, although they had stronger background signals (data not shown).

\section{Immunofluorescent Detection}

Worms were fixed using a modified Bouin's fixative as described by Nonet et al. (1997). Briefly, animals grown on NGM plates were washed with M9 buffer, collected with gentle centrifugation, and mixed with 10 volumes of modified Bouin's fixative (saturated picric acid-formalin-glacial acetic acid-methanol- $\beta$-mercaptoethanol $=750: 250: 5: 330: 16)$. The animals were incubated with the fixative for $15 \mathrm{~min}$ at room temperature with gentle rotation, frozen with liquid nitrogen, quickly thawed to room temperature, and incubated for an additional $15 \mathrm{~min}$. The fixed animals were then washed with BTB $\left(20 \mathrm{mM} \mathrm{H}_{3} \mathrm{BO}_{3}, 10 \mathrm{mM} \mathrm{NaOH}, 0.5 \%\right.$ Triton $\mathrm{X}-100,2 \% \beta$-mercaptoethanol) five times during $3 \mathrm{~h}$. Fixed animals were then briefly washed with BT (BTB without $\beta$-mercaptoethanol) and incubated with BT with $0.3 \% \mathrm{H}_{2} \mathrm{O}_{2}$ for $15 \mathrm{~min}$ for irreversible oxidization of the sulfhydryl groups to sulfonic acid. Fixed animals were then washed with BT twice and once with antibody buffer A (AbA; $1 \times$ PBS, 1\% BSA, $0.5 \%$ Triton X-100, $10 \mathrm{mM} \mathrm{NaN}_{3}$ ) and stored at $4{ }^{\circ} \mathrm{C}$ in $\mathrm{AbA}$. The fixed worms were stable for a few months in the buffer. The fixed worms were incubated with primary and secondary antibodies essentially as described by Finney and Ruvkun (1990). Primary antibodies were diluted 1:10 with AbA and incubated with the fixed worms overnight at $4^{\circ} \mathrm{C}$ with gentle rotation. The worms were then washed for $4 \mathrm{~h}$-overnight with several changes of NP-40 buffer (20 mM Tris [pH 7.5], $150 \mathrm{mM} \mathrm{NaCl}, 5 \mathrm{~mm}$ EDTA, 1\% NP-40) and incubated with Cy3-labeled antirabbit IgG goat antibodies (Amersham) 1:1000 in AbA, $4 \mathrm{~h}$-overnight. After washing as before with NP-40 buffer, the worms were mounted for microscopy. Mounting and visualization were as described previously (Ruvkun and Giusto 1989).

\section{ACKNOWLEDGMENTS}

We thank Ian Caldicott for the isolation and genetic mapping of the nontemperature sensitive daf-2 mutant alleles, Y. Liu for technical support, and S. ImajoOhmi, S.-i. Takahashi, and members of the Ruvkun Laboratory for helpful discussions. Some of the strains were obtained from the Caenorhabditis Genetics Center, which is supported by the National Institutes of Health National Center for Research Resources. The work was supported by National Institutes of Health grant AG14161. K.D.K. was supported by the Japanese Society for the Promotion of Science.

\section{REFERENCES}

Aleman A, Torres-Aleman I. 2009. Circulating insulin-like growth factor I and cognitive function: Neuromodulation throughout the lifespan. Prog Neurobiol 89: 256-265.

Apfeld J, Kenyon C. 1998. Cell nonautonomy of C. elegans daf-2 function in the regulation of diapause and life span. Cell 95: 199-210.

Apfeld J, O'Connor G, McDonagh T, DiStefano PS, Curtis R. 2004. The AMP-activated protein kinase AAK-2 links energy levels and insulin-like signals to lifespan in C. elegans. Genes Dev 18: 3004-3009.

Ashcroft FM, Proks P, Smith PA, Ammala C, Bokvist K, Rorsman P. 1994. Stimulus-secretion coupling in pancreatic $\beta$ cells. J Cell Biochem 55(suppl): 54-65.

Bartke A, Brown-Borg HM, Bode AM, Carlson J, Hunter WS, Bronson RT. 1998. Does growth hormone prevent or accelerate aging? Exp Gerontol 33: 675-687.

Blair LA, Marshall J. 1997. IGF-1 modulates N and L calcium channels in a PI 3-kinase-dependent manner. Neuron 19: $421-429$

Blair LA, Bence-Hanulec KK, Mehta S, Franke T, Kaplan D, Marshall J. 1999. Akt-dependent potentiation of L channels by insulin-like growth factor-1 is required for neuronal survival. J Neurosci 19: 1940-1951.

Bokvist K, Eliasson L, Ammala C, Renstrom E, Rorsman P. 1995. Co-localization of L-type $\mathrm{Ca}^{2+}$ channels and insulincontaining secretory granules and its significance for the initiation of exocytosis in mouse pancreatic B-cells. EMBO J 14: 50-57.

Brown-Borg HM, Borg KE, Meliska CJ, Bartke A. 1996. Dwarf mice and the ageing process. Nature 384: 33

Bruning JC, Gautam D, Burks DJ, Gillette J, Schubert M, Orban PC, Klein R, Krone W, Muller-Wieland D, Kahn CR. 2000. Role of brain insulin receptor in control of body weight and reproduction. Science 289: 2122-2125.

Butcher RA, Fujita M, Schroeder FC, Clardy J. 2007. Smallmolecule pheromones that control dauer development in Caenorhabditis elegans. Nat Chem Biol 3: 420-422.

Dorman JB, Albinder B, Shroyer T, Kenyon C. 1995. The age-1 and $d a f-2$ genes function in a common pathway to control the lifespan of Caenorhabditis elegans. Genetics 141: 1399-1406.

Finch CE, Ruvkun G. 2001. The genetics of aging. Annu Rev Genomics Hum Genet 2: 435-462.

Finney M, Ruvkun G. 1990. The unc-86 gene product couples cell lineage and cell identity in $C$. elegans. Cell 635: 895-905.

Garcia-Segura LM, Rodriguez JR, Torres-Aleman I. 1997. Localization of the insulin-like growth factor I receptor in the cerebellum and hypothalamus of adult rats: An electron microscopic study. J Neurocytol 26: 479-490.

Gems D, Sutton AJ, Sundermeyer ML, Albert PS, King KV, Edgley ML, Larsen PL, Riddle DL. 1998. Two pleiotropic classes of daf-2 mutation affect larval arrest, adult behavior, reproduction and longevity in Caenorhabditis elegans. Genetics 150: 129-155.

Gerisch B, Antebi A. 2004. Hormonal signals produced by DAF-9/cytochrome $\mathrm{P} 450$ regulate $C$. elegans dauer diapause in response to environmental cues. Development 131: $1765-1776$.

Golden JW, Riddle DL. 1982. A pheromone influences larval development in the nematode Caenorhabditis elegans. Science 218: $578-580$. 
Golden JW, Riddle DL. 1984. The Caenorhabditis elegans dauer larva: Developmental effects of pheromone, food, and temperature. Dev Biol 102: 368-378.

Gottlieb S, Ruvkun G. 1994. daf-2, daf-16 and daf-23: Genetically interacting genes controlling Dauer formation in Caenorhabditis elegans. Genetics 137: 107-120.

Graf R, Neuenschwander S, Brown MR, Ackermann U. 1997. Insulin-mediated secretion of ecdysteroids from mosquito ovaries and molecular cloning of the insulin receptor homologue from ovaries of bloodfed Aedes aegypti. Insect Mol Biol 6: 151-163.

Hansen M, Chandra A, Mitic LL, Onken B, Driscoll M, Kenyon C. 2008. A role for autophagy in the extension of lifespan by dietary restriction in C. elegans. PLoS Genet 4: e24.

Ishizaki H, Suzuki A. 1994. The brain secretory peptides that control moulting and metamorphosis of the silkmoth, Bombyx mori. Int J Dev Biol 38: 301-310.

Jeong PY, Jung M, Yim YH, Kim H, Park M, Hong E, Lee W, Kim YH, Kim K, Paik YK. 2005. Chemical structure and biological activity of the Caenorhabditis elegans dauer-inducing pheromone. Nature 433: 541-545.

Jonas EA, Knox RJ, Smith TC, Wayne NL, Connor JA, Kaczmarek LK. 1997. Regulation by insulin of a unique neuronal $\mathrm{Ca}^{2+}$ pool and of neuropeptide secretion. Nature 385: 343-346.

Kahn CR, Weir GC, eds. 1994. Joslin's diabetes mellitus. Williamas \& Wilkins, Baltimore.

Kenyon C, Chang J, Gensch E, Rudner A, Tabtiang R. 1993. A C. elegans mutant that lives twice as long as wild type. [See comments.] Nature 366: 461-464.

Kimura KD, Tissenbaum HA, Liu Y, Ruvkun G. 1997. daf-2, An insulin receptor-like gene that regulates longevity and diapause in Caenorhabditis elegans. Science 277: 942-946.

Kulkarni RN, Bruning JC, Winnay JN, Postic C, Magnuson MA, Kahn CR. 1999. Tissue-specific knockout of the insulin receptor in pancreatic $\beta$ cells creates an insulin secretory defect similar to that in type 2 diabetes. Cell 96: 329-339.

Larsen PL, Albert PS, Riddle DL. 1995. Genes that regulate both development and longevity in Caenorhabditis elegans. Genetics 139: 1567-1583.

LeRoith D, Parrizas M, Blakesley VA. 1997. The insulin-like growth factor-I receptor and apoptosis. Implications for the aging progress. Endocrine 7: 103-105.

Morris JZ, Tissenbaum HA, Ruvkun G. 1996. A phosphatidylinositol-3-OH kinase family member regulating longevity and diapause in Caenorhabditis elegans. Nature 382: 536539.

Nonet ML, Staunton JE, Kilgard MP, Fergestad T, Hartwieg E, Horvitz HR, Jorgensen EM, Meyer BJ. 1997. Caenorhabditis elegans rab-3 mutant synapses exhibit impaired function and are partially depleted of vesicles. J Neurosci 17: 8061-8073.

Ogg S, Ruvkun G. 1998. The C. elegans PTEN homolog, DAF-18, acts in the insulin receptor-like metabolic signaling pathway. Mol Cell 2: 887-893.

Ogg S, Paradis S, Gottlieb S, Patterson GI, Lee L, Tissenbaum HA, Ruvkun G. 1997. The Fork head transcription factor DAF-16 transduces insulin-like metabolic and longevity signals in C. elegans. Nature 389: 994-999.

Ohkura K, Suzuki N, Ishihara T, Katsura I. 2003. SDF-9, a protein tyrosine phosphatase-like molecule, regulates the L3/ dauer developmental decision through hormonal signaling in C. elegans. Development 130: 3237-3248.

Paradis S, Ruvkun G. 1998. Caenorhabditis elegans Akt/PKB transduces insulin receptor-like signals from AGE-1 PI3 kinase to the DAF-16 transcription factor. Genes Dev 12: $2488-$ 2498.

Paradis S, Ailion M, Toker A, Thomas JH, Ruvkun G. 1999. A PDK1 homolog is necessary and sufficient to transduce
AGE-1 PI3 kinase signals that regulate diapause in Caenorhabditis elegans. Genes Dev 13: 1438-1452.

Patel DS, Garza-Garcia A, Nanji M, McElwee JJ, Ackerman D, Driscoll PC, Gems D. 2008. Clustering of genetically defined allele classes in the Caenorhabditis elegans DAF-2 insulin/ IGF-1 receptor. Genetics 178: 931-946.

Pierce SB, Costa M, Wisotzkey R, Devadhar S, Homburger SA, Buchman AR, Ferguson KC, Heller J, Platt DM, Pasquinelli AA, et al. 2001. Regulation of DAF-2 receptor signaling by human insulin and ins-1, a member of the unusually large and diverse C. elegans insulin gene family. Genes Dev 15: 672-686.

Plum L, Schubert M, Bruning JC. 2005. The role of insulin receptor signaling in the brain. Trends Endocrinol Metab 16: $59-65$.

Porte D Jr, Baskin DG, Schwartz MW. 2005. Insulin signaling in the central nervous system: A critical role in metabolic homeostasis and disease from C. elegans to humans. Diabetes 54: $1264-1276$.

Riddle DL, Albert PS. 1997. Genetic and environmental regulation of dauer larva development. In C. elegans II (ed. Riddle D, et al.), 739-768. Cold Spring Harbor Laboratory Press, Cold Spring Harbor, NY.

Ruvkun G, Giusto J. 1989. The Caenorhabditis elegans heterochronic gene lin-14 encodes a nuclear protein that forms a temporal developmental switch. Nature 338: 313-319.

Schwartz MW, Woods SC, Porte D Jr, Seeley RJ, Baskin DG. 2000. Central nervous system control of food intake. Nature 404: $661-671$.

Sulston J, Hodgkin J. 1988. Methods. In The nematode Caenorhabditis elegans (ed. Wood WB), pp. 587-606. Cold Spring Harbor Laboratory Press, Cold Spring Harbor, NY.

Swanson MM, Riddle DL. 1981. Critical periods in the development of the Caenorhabditis elegans dauer larva. Dev Biol 84: $27-40$.

Taguchi A, White MF. 2008. Insulin-like signaling, nutrient homeostasis, and life span. Annu Rev Physiol 70: 191-212.

Thomas JH. 2006. Analysis of homologous gene clusters in Caenorhabditis elegans reveals striking regional cluster domains. Genetics 172: 127-143.

Thomas JH, Birnby DA, Vowels JJ. 1993. Evidence for parallel processing of sensory information controlling dauer formation in Caenorhabditis elegans. Genetics 134: 1105-1117.

Tomioka M, Adachi T, Suzuki H, Kunitomo H, Schafer WR, Iino Y. 2006. The insulin/PI 3-kinase pathway regulates salt chemotaxis learning in Caenorhabditis elegans. Neuron 51: 613-625.

Tsuji N, Tsujimoto K, Takada N, Ozaki K, Ohta M, Itoh N. 1996. Expression of insulin receptor-related receptor in the rat brain examined by in situ hybridization and immunohistochemistry. Brain Res Mol Brain Res 41: 250-258.

Viard P, Butcher AJ, Halet G, Davies A, Nurnberg B, Heblich F, Dolphin AC. 2004. PI3K promotes voltage-dependent calcium channel trafficking to the plasma membrane. Nat Neurosci 7: 939-946.

Vowels JJ, Thomas JH. 1992. Genetic analysis of chemosensory control of dauer formation in Caenorhabditis elegans. Genetics 130: 105-123.

Werner H, Le Roith D. 1997. The insulin-like growth factor-I receptor signaling pathways are important for tumorigenesis and inhibition of apoptosis. Crit Rev Oncog 8: 71-92.

White J, Southgate E, Thomson J, Brenner S. 1986. The structure of the nervous system of the nematode Caenorhabditis elegans. Phil Trans $R$ Soc Lond B Biol Sci 314: $1-340$.

Wolkow CA, Kimura KD, Lee MS, Ruvkun G. 2000. Regulation of $C$. elegans life-span by insulinlike signaling in the nervous system. Science 290: 147-150. 


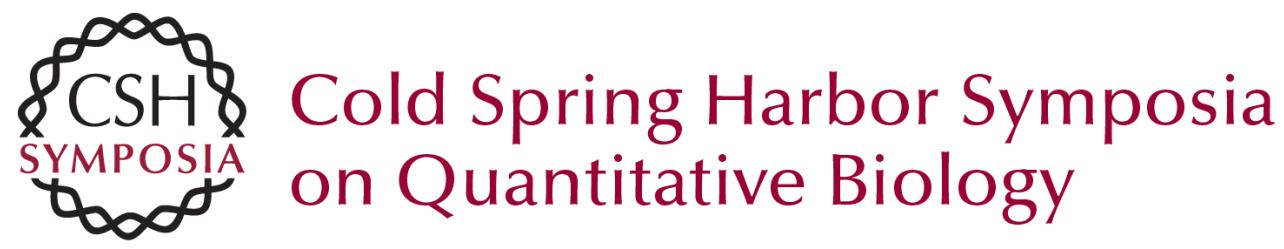

\section{The C. elegans DAF-2 Insulin-Like Receptor is Abundantly Expressed in the Nervous System and Regulated by Nutritional Status}

K.D. Kimura, D.L. Riddle and G. Ruvkun

Cold Spring Harb Symp Quant Biol 2011 76: 113-120 originally published online November 28, 2011

Access the most recent version at doi:10.1101/sqb.2011.76.010660

References This article cites 54 articles, 13 of which can be accessed free at: http://symposium.cshlp.org/content/76/113.full.html\#ref-list-1

License

Email Alerting Receive free email alerts when new articles cite this article - sign up in Service the box at the top right corner of the article or click here. 